\title{
Dylan under the microscope: microbiology in Subterranean Homesick Blues
}

\author{
G. T. Rijkers ${ }^{1,2}$
}

Received: 29 August 2017 / Accepted: 29 August 2017 /Published online: 14 September 2017

(C) Springer-Verlag GmbH Germany 2017

Titles of songs by Nobel Prize winner Bob Dylan are regularly quoted in biomedical publications [1]. The most quoted Dylan songs in the titles of biomedical publications are The Times They Are a-Changin' $(n=125)$ and Blowin' in the Wind $(n=38)$. In the singles chronology of Bob Dylan, the song released directly after The Times They Are a-Changin' is Subterranean Homesick Blues, Dylan's first international hit song [2]. Unfortunately, not a single scientist from the biomedical sciences has ever used it in the title of a publication. This song is likely to be remembered better for its video clip than the music [3]. In fact, the video clip is the opening segment of the documentary movie "Dont Look Back" by Donn Alan Pennebaker from 1967. Dylan has the keywords of the song written on a stack of cue cards which fall like autumn leaves. Some of the words are deliberately misspelled or differ from the authentic lyrics. All of this in the spirit of the Beat poets, co-emphasized by the appearance of Allen Ginsberg in the video and the title of the poem/song being inspired by the novel "The Subterraneans" by Jack Kerouac (1958).

Dylan is a poet and a poet is a storyteller. What exactly the story is, is left to the reader. At first glance, one would say the song is about a drug addict reflecting on years of innocence long gone by. Others associate the text with civil rights issues and police violence [4]. Never before was this song interpreted in the context of infection and

G. T. Rijkers

g.rijkers@ucr.nl

1 Science Department, University College Roosevelt, Room E 1.14, Lange Noordstraat 1, 4331 CB Middelburg, The Netherlands

2 Laboratory of Medical Microbiology and Immunology, St. Antonius Hospital, Nieuwegein, The Netherlands immunity, most likely the real meaning of the poem/song, at least to a (biased) biomedical scientist.

So what do the 71 lines of text, sung in $2 \mathrm{~min} 20 \mathrm{~s}$ tell us [2]? The opening lines Johnny's in the basement, mixing up the medicine serves as an introduction of what is to come. It promises a good story without giving away the bottom line. Next is a man in a trench coat. He says he's got a bad cough. We do not know whether this is bacterial or viral, and, therefore, cannot recommend any specific medicine. Whatever it will be, he wants his bad cough to get paid off. For any microbiology student, it is important to realize that infections are not loans: they need treatment, not paying off. Get sick, get well. When you get sick by an infectious disease, it is the response of the immune system which will ultimately clear the invading micro-organism, allowing you to get well. This line is used often in introductory immunology lectures. The get sick, get well line is followed almost immediately by hard to tell If anything is goin' to sell Try hard, get barred. Without probably realizing it, Dylan here gives a well-meant advice for overzealous sales representatives of antibiotics...

The most direct reference to microbiology and infectious diseases comes in the last two lines of the song: The pump don't work' Cause the vandals took the handles. This is a clear link to the police officers (who also may have been vandals, certainly in the view of Dylan in the mid-1960s in the USA) who removed, at the request of John Snow, the handle of the water pump in Broad Street, Soho, London and this caused an end to the cholera epidemic of 1854 [5].

Apart from the clear-cut microbiology undertone, the song has a number of relevant lifestyle advices: do not steal, do not wear sandals, do not try "No-Doz", and, most importantly, do not follow leaders. Dylan appears to deal with infection and immunity more often, especially on the "The Other Side of Bob Dylan" album [6], which warrants a more in-depth infectious diseases investigation of his complete oeuvre. 
Funding No external funding was used for this work.

\section{Compliance with ethical standards}

Ethical approval Ethical approval and informed consent are not applicable.

Conflict of interest Apart from the author being a Bob Dylan fan, there is no conflict of interest.

\section{References}

1. Gornitzki C, Larsson A, Fadeel B (2015) Freewheelin' scientists: citing Bob Dylan in the biomedical literature. BMJ 351:h6505. https://doi.org/10.1136/bmj.h6505
2. Bob Dylan: Subterranean Homesick Blues. Accessed on August 9 2017 from: https://bobdylan.com/songs/subterranean-homesickblues/

3. You Tube. Bob Dylan: Subterranean Homesick Blues. Accessed on August 92017 from: https://www.youtube.com/watch?v= MGxjIBEZvx0

4. Voss M (2011) Lyrical analysis of Bob Dylan's "Subterranean Homesick Blues". Accessed on August 92017 from: https:// mikevosswriting.wordpress.com/2012/02/03/lyrical-analysis-ofbob-dylans-subterranean-homesick-blues/

5. Parkes EA (2013) Mode of communication of cholera by John Snow, MD: second edition-London, 1855, pp 162. Int J Epidemiol 42: 1543-1552. https://doi.org/10.1093/ije/dyt193

6. Rijkers GT (2017) The function of the immune system according to The Other Side of Bob Dylan. Eur J Immunol 47:1094-1095. https:// doi.org/10.1002/eji.201770075 